\title{
The age, geochemistry and petrogenesis of an unusual alkaline intrusion in the western Pilbara craton, Western Australia
}

\author{
Erin Matchan \\ School of Earth Sciences, University of Melbourne
}

\section{Introduction}

The recently discovered Yanyare dykes are located approximately $50 \mathrm{~km} \mathrm{SSW}$ of Karratha in the northeastern Pilbara craton. The Yanyare- 02 dyke is the subject of this study. It is approximately $5 \mathrm{~km}$ long and 2-3 m wide, striking NNE. It intrudes intercalated sedimentary and volcanic units of the Palaeoproterozoic Fortescue Group $(2775 \pm 10 \mathrm{Ma}$ to $2690 \pm 16 \mathrm{Ma}$, (Arndt et al., 1991)). Excluding calcretisation of the upper $10 \mathrm{~m}$, the dyke appears relatively unaltered in hand-specimen. This study investigates the age and geochemistry of Yanyare-02 and explores possible models of formation.

\section{Petrography and mineral chemistry}

Thin-section inspection reveals an inequigranular texture comprised of intensely altered macrocrysts set in a matrix of phlogopite $(55 \%)$, sanidine $(20 \%)$ and apatite (5\%). Phlogopite also occurs as ubiquitous coronae on macrocrysts and as microphenocrysts. Replacement of phlogopite by rutile and chlorite is common, but several chips are dominated by alteration of phlogopite to sodic amphibole. Sanidine occurs as euhedral grains and poikilitic plates enclosing apatite and is variably altered to muscovite and calcite. Macrocrysts appear to be dominantly relict olivine grains. Crustal xenoliths are also present, as are rare mantle xenoliths. Aside from apatite, which electronmicroprobe analyses revealed to be fluorapatite $(n=18)$, no accessory minerals were observed. Chemical zonation of phlogopite, has been found to be a key tool in the classification of alkaline rocks (Mitchell and Bergman, 1991). Core-to-rim electron-microprobe traverses of phlogopite phenocrysts $(n=42)$ reveal increasing $\mathrm{FeO}$ T- contents with $\mathrm{Al}_{2} \mathrm{O}_{3}$, but a mixture of both increasing and decreasing $\mathrm{TiO}_{2}$ and $\mathrm{SiO}_{2}$. Evolutionary trends best compare with those observed in phlogopites from minettes, as opposed to lamproites or Group II kimberlites (as described by Mitchell and Bergmann, 1991).

\section{Geochemistry}

Average major element contents compare well with both olivine lamproites and calc-alkaline lamprophyres. Trace element data reveal extreme LREE enrichment, with LaN/Lun $\approx 100$. The enrichment in both incompatible and compatible trace elements is similar to average values for both calcalkaline lamprophyres and lamproites (see Fig. 1).

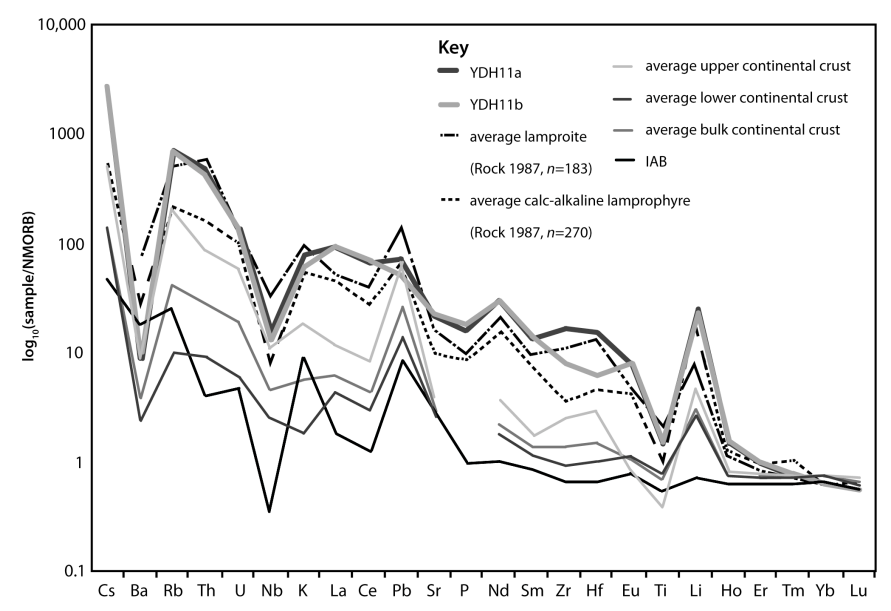

Fig. 1 N-MORB normalised spider diagram, using normalising values of Sun and McDonough (1989) for, comparing YDH11a and YDH11b (best estimates of melt composition of Yanyare-02) with average values for continental crust (Taylor and McLennan, 1981), calcalkaline lamprophyres, lamproites and island-arc basalt.

In a similar fashion to lamproites and Group II kimberlites, Yanyare-02 departs from the mantle array and exhibits subchondritic $\varepsilon \mathrm{Hf}$ and $\varepsilon \mathrm{Nd}$ values (see Fig. 2). Average initial $(1.72 \mathrm{Ga})$ isotope ratios for Yanayare-02 are: ${ }^{87} \mathrm{Sr} /{ }^{86} \mathrm{Sr}_{\mathrm{i}}=0.708 ;{ }^{143} \mathrm{Nd} /{ }^{144} \mathrm{Nd}_{\mathrm{i}}=$ 0.510 ; and ${ }^{176} \mathrm{Hf} /{ }^{177} \mathrm{Hf}_{\mathrm{i}}=0.281(n=6)$. 


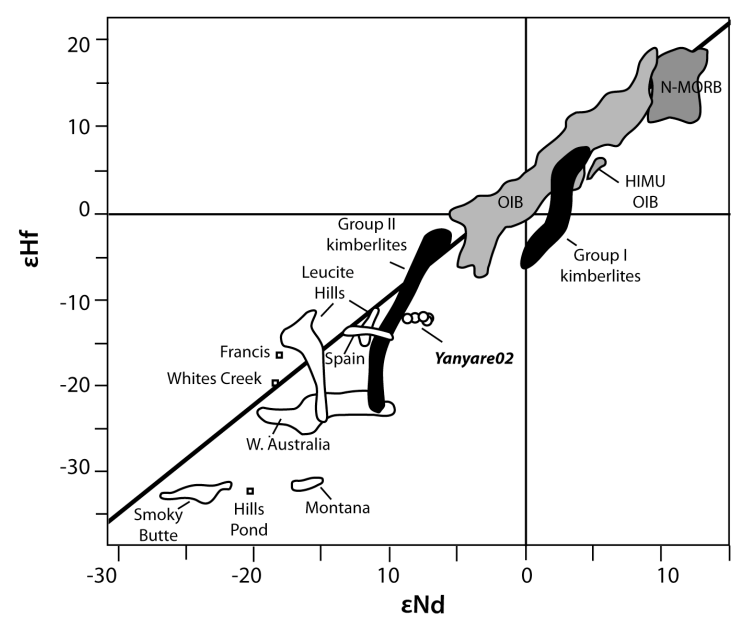

Fig. 2 Modified from Nowell et al. (1998). Comparison of Yanyare-02 in $\varepsilon H f-\varepsilon N d$ space with N-MORB (dark grey), OIB (grey), Group I \& II kimberlites (black) and several lamproite provinces (white). Solid black line is the mantle array as defined by Vervoort et al. (1999): $\varepsilon H f=1.33 \varepsilon N d+3.19$.

\section{Geochronology}

$\mathrm{A}{ }^{40} \mathrm{Ar} /{ }^{39} \mathrm{Ar}$ weighted mean age of $1724 \pm 8 \mathrm{Ma}(2 \sigma)$ was calculated from the high temperature steps of incremental heating analyses of euhedral phlogopite grains $(n=6) . \mathrm{Rb}-\mathrm{Sr}$ analyses of whole-rock and phlogopite separates gave two-point isochron ages of $1675 \pm 10 \mathrm{Ma}$ and $1689 \pm 10 \mathrm{Ma}(2 \sigma)$. Mobilisation of $\mathrm{Sr}$ by near-surface alteration processes may partially explain the $50 \mathrm{Ma}$ discrepancy with the ${ }^{40} \mathrm{Ar} /{ }^{39} \mathrm{Ar}$ age results. It is clear from comparison of $\mathrm{Sm}-\mathrm{Nd}$ and $\mathrm{Rb}$ $\mathrm{Sr}$ isotope systematics that $\mathrm{Sr}$ content has been variably affected by alteration processes across the Yanyare- 02 subsamples. Due to both intra- and inter- grain reproducibility of ages from ${ }^{40} \mathrm{Ar} /{ }^{39} \mathrm{Ar}$ laser probe step heating analyses of phlogopite, it seems that excess ${ }^{40} \mathrm{Ar}$ is unlikely to be a problem (e.g. Phillips et al., 1999). Four of the six ${ }^{40} \mathrm{Ar}-{ }^{39} \mathrm{Ar}$ step-heating analyses yield age plateaus that are indistinguishable at the $95 \%$ confidence level (the remaining two analyses had insufficient steps to construct age plateaus).

\section{Discussion}

Yanyare-02 displays strong mineralogical and chemical affinities with both olivine lamproites and calc-alkaline lamprophyres. On the basis of geochemistry, mineralogy and phlogopite chemistry combined, Yanayare-02 is best classified as an olivine-phlogopitesanidine calc-alkaline lamprophyre. A sub-continental lithospheric origin is proposed for Yanayare-02, involving an ancient, subducted slab of oceanic crust. A time-integrated oceanic crust component is thought to be responsible for the negative $\Delta \varepsilon \mathrm{Hf}$ signature and some anomalies in the trace element pattern (e.g. Nowell et al., 1999). The absence of diamonds or diamond indicator minerals supports a relatively shallow origin.
No tectonic event is recognised to have occurred in the Pilbara around the determined age of intrusion (1724 \pm $8 \mathrm{Ma}$ ). Other Palaeoproterozoic alkaline bodies in the Pilbara include the diamondiferous Nabberu kimberlites in the south-east of the craton, which are geologically constrained to be $\sim 1900 \mathrm{Ma}$, with associated barren lamprophyres bracketed at 1900$1700 \mathrm{Ma}$ (Shee et al., 1999). Yanyare-02 may be part of a prolonged Palaeoproterozoic history of deepseated magmatism occurring across the Pilbara. This raises the potential for discovery of diamondiferous bodies in the west of the craton. It would be interesting to determine the age of the diamondiferous Blacktop Kimberlite located less than $50 \mathrm{~km}$ to the south-east, but unfortunately this body has been deemed too weathered for radiometric dating ( $\mathrm{S}$. Shee pers. comm.. 2006).

\section{References}

Arndt, N.T., Nelson, D.R., Compston, W., Trendall, A.F. and Thorne, A.M. (1991) The age of the Fortescue Group, Hamersley Basin, Western Australia, from ion microprobe zircon U-Pb results. Australian Journal of Earth Sciences, 38, 261-81.

Mitchell, R.H. and Bergman, S.C. (1991). Petrology of Lamproites, Plenum Press, New York.

Nowell, G.M., Pearson, D.G., Kempton, P.D., Irving, A.J., and Turner, S., (1998). A Hf study of lamproites: implications for their origins and relationship to kimberlites. Extended Abstracts, $7^{\text {th }}$ International Kimberlite Conference Cape Town. pp. 637-639.

Nowell, G.M., Pearson, D.G., Kempton, P.D., Noble, S.R. and Smith, C.B. (1999). Origins of kimberlites: a Hf isotope perspective. In: J.J. Gurney, J.L. Gurney, M.D. Pascoe, and S.H. Richardson, (Eds.), Proceedings of the 7th International Kimberlite Conference, Cape Town. Goodwood, S. Africa: National Book Printer, pp. 616-624.

Phillips, D., Kirets, G.B., Barton, E.S. Smith, C.B. Viljoen, K.S. and Fourie, L.F. (1999) ${ }^{40} \mathrm{Ar} /{ }^{39} \mathrm{Ar}$ dating of kimberlites and related rocks: problems and solutions. In: J.J. Gurney, J.L. Gurney, M.D. Pascoe, and S.H. Richardson, (Eds), Proceedings of the 7th International Kimberlite Conference, Cape Town. Goodwood, S. Africa: National Book Printer, pp. 677-688.

Rock, N.M.S. (1987) The nature and origin of lamprophyres: An overview. In: J.G.F. and B.G. Upton, (Eds.), Geological Society of Australia Special Publication 30, pp. 191-226.

Sun, S.S. and McDonough W.F. (1989). Chemical and isotopic systematics of oceanic basalts; implicatoins for mantle composition and processes. In: A.D. Saunders and M.J. Norry, (Eds.), Magmatism in Ocean Basins, Geological Society Special Publication 42, pp. 359-362.

Shee, S.R., Vercoe, S.C., Wyatt, B.A., Hwang, P.H., Campbell, A.N. and Colgan, E.A. (1999). Discovery and geology of the Nabberu kimberlite province, Western Australia. In J.J. Gurney, J.L. Gurney, M.D. Pascoe, and S.H. Richardson, (Eds.), Proceedings of the 7th International Kimberlite Conference, Cape Town. Goodwood, S. Africa: National Book Printer, pp. 764-72. 
Taylor, S.R. and McLennan, S.M. (1981). The composition and evolution of the Earth's crust; rare earth element evidence from sedimentary rocks, Philosophical Transaction of the Royal Society of London A, 301 (1461), 381-399.

Vervoort, J., Patchett, P., Blichert-Toft, J. and Albarede, F. (1999). Relationships between the Lu-Hf and Sm-Nd isotopic systems in the global sedimentary system. Earth and Planetary Science Letters, 168, 79-99. 